\title{
A case of erythroderma in an oil painting at Tate Britain
}

\section{Kluger, Nicolas}

2020-10

Kluger , N 2020 , ' A case of erythroderma in an oil painting at Tate Britain ', Journal of the

European Academy of Dermatology and Venereology , vol. 34 , no. 10 , pp. E622-E623 . https://doi.org/10.1111/jdv.

http://hdl.handle.net/10138/329215

https://doi.org/10.1111/jdv.16499

unspecified

acceptedVersion

Downloaded from Helda, University of Helsinki institutional repository.

This is an electronic reprint of the original article.

This reprint may differ from the original in pagination and typographic detail.

Please cite the original version. 
DR. NICOLAS KLUGER (Orcid ID : 0000-0002-5225-8316)

Article type : Letter to Editor

Historical Perspectives

Journal of the European academy of Dermatology and Venereology

\section{A case of erythroderma in an oil painting at Tate Britain}

Nicolas Kluger ${ }^{1,2}$

${ }^{1}$ Department of dermatology, allergology and venereology, Helsinki University Hospital, Helsinki, Finlande

${ }^{2}$ Société française des sciences humaines sur la peau (SFSHP), Maison de la dermatologie, 10, cité Malesherbes, 75009 Paris, France.

Electronic address: nicolas.kluger@hus.fi.

Key-word: art, erythroderma, iconodiagnosis, painting, redness

Conflict of interest: none declared

This article has been accepted for publication and undergone full peer review but has not been through the copyediting, typesetting, pagination and proofreading process, which may lead to differences between this version and the Version of Record. Please cite this article as doi: $\underline{10.1111 / J D V .16499}$

This article is protected by copyright. All rights reserved 
Funding sources: none declared

Word count: 360

Figures. The Administration, loan and reproduction fee have been payed by the author to Tate Images

Editor,

The oil canvas "Punch or May Day" (1829) by British painter Benjamin Robert Haydon (1786-1846) is exhibited at Tate Britain in London [1,2]. The painting theatrically depicts a colorful London-street scene not far from St Marylebone church during May Day a bit after noon. The crowd attends Punch and Judy puppet show in the middle of the street and blocks the coaches' traffic (Figure 1). Among the 25 characters in this painting, a seeming aged-man 
wearing a creamy white coat and top hat stands out. He has his pocket picked deftly by a small hand while gawping [2]. His skin tone contrasts from the other characters nearby, who have a light or dark skin. He displays a bright diffuse facial redness without any normal appearing skin. A closer look shows additional details such as deep wrinkles on the forehead and on the corner of eye (Crow's feet), sparse frontal and temporal alopecia, graying hairs, and no visible eyebrows or eyelids. The skin seems dry, but not scaly, the lips are thin and the hands are red-orange (Figure 2).

The painting analysis was performed as previously described $[3,4]$. The author first screened paintings at Tate Britain for 30 seconds from a distance of $1 \mathrm{~m}$, concentrating on face, hands and all exposed skin, and then stepped closer for details analysis. The character has features suggestive of chronic erythroderma: bright redness, lack of visible eyebrows and of eyelids, marked wrinkles, sparse alopecia, and thin lips. The redness is not evocative of rosacea. Besides, artists usually suggest alcohol-associated facial redness with additional clues in the painting like alcoholic beverages. Several characters have here stylistic redness on the cheeks [4], which support that the striking redness of this man is not a stylistic choice. Differential diagnoses include here adult atopic dermatitis, chronic actinic dermatitis, pityriasis rubra pilaris or Sezary syndrome. In the literature, Dequeker et al identified a possible case of mycosis fungoides in a painting by Lambert Lombard [5], but we failed to find other case similar as the present one. With all the cautions and limitations surrounding the practice of iconodiagnosis, Haydon may have portrayed here an individual with chronic erythroderma.

\section{References}

1. Tate. Punch or May Day (1829). July 2018 https://www.tate.org.uk/art/artworks/haydonpunch-or-may-day-n00682 [accessed 27 March 2020]

2. Glover M. Great works: Punch or May Day (1830) By Benjamin Robert Haydon. Independent. 28 June 2013 https://www.independent.co.uk/arts- 
entertainment/art/great-works/great-works-punch-or-may-day-1830-by-benjaminrobert-haydon-8679006.html [accessed 27 March 2020]

3. Kluger N. Skin abnormalities in the Finnish National Gallery. J Cosmet Dermatol. 2019 Aug 24. doi: 10.1111/jocd.13095.

4. Strauss RM, Marzo-Ortega $\mathrm{H}$, Goulden V. Skin abnormalities in the National Portrait Gallery. J Eur Acad Dermatol Venereol. 2004; 18: 566-568.

5. Dequeker J, Degreef H, Busschots AM, Mallia C. Mycosis fungoides in a painting by Lambert Lombard (1506-1566). Dermatology. 2002;205:78-9.

\section{Figure legends}

Figure 1. Punch or May Day (1829), Benjamin Robert Haydon, Tate Britain. Photo (C Tate

Figure 2. Detail view. Notice the diffuse redness of the face, wrinkles, lack of eyebrows and eyelids, sparse alopecia and redness of the hand. 


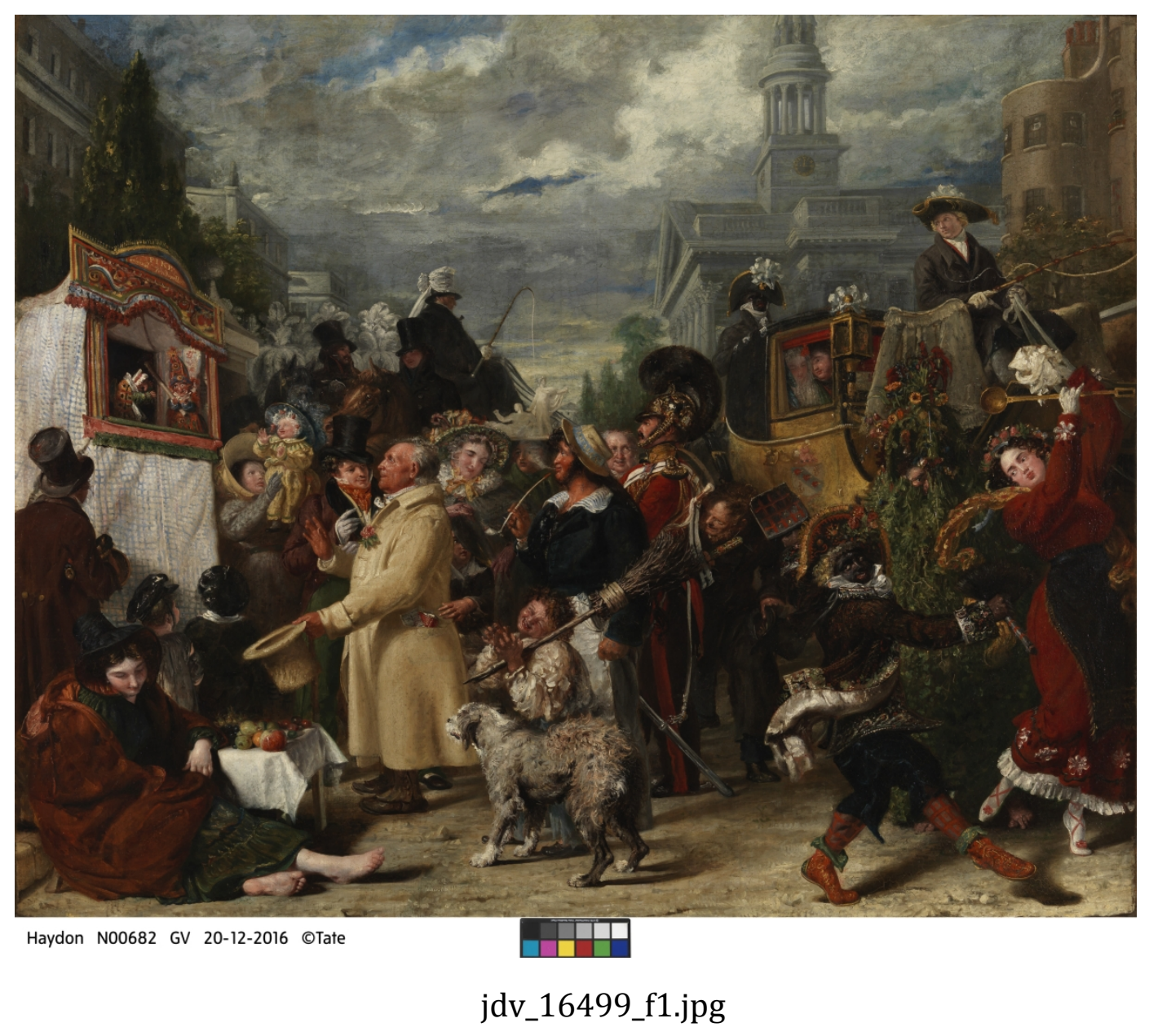

This article is protected by copyright. All rights reserved 


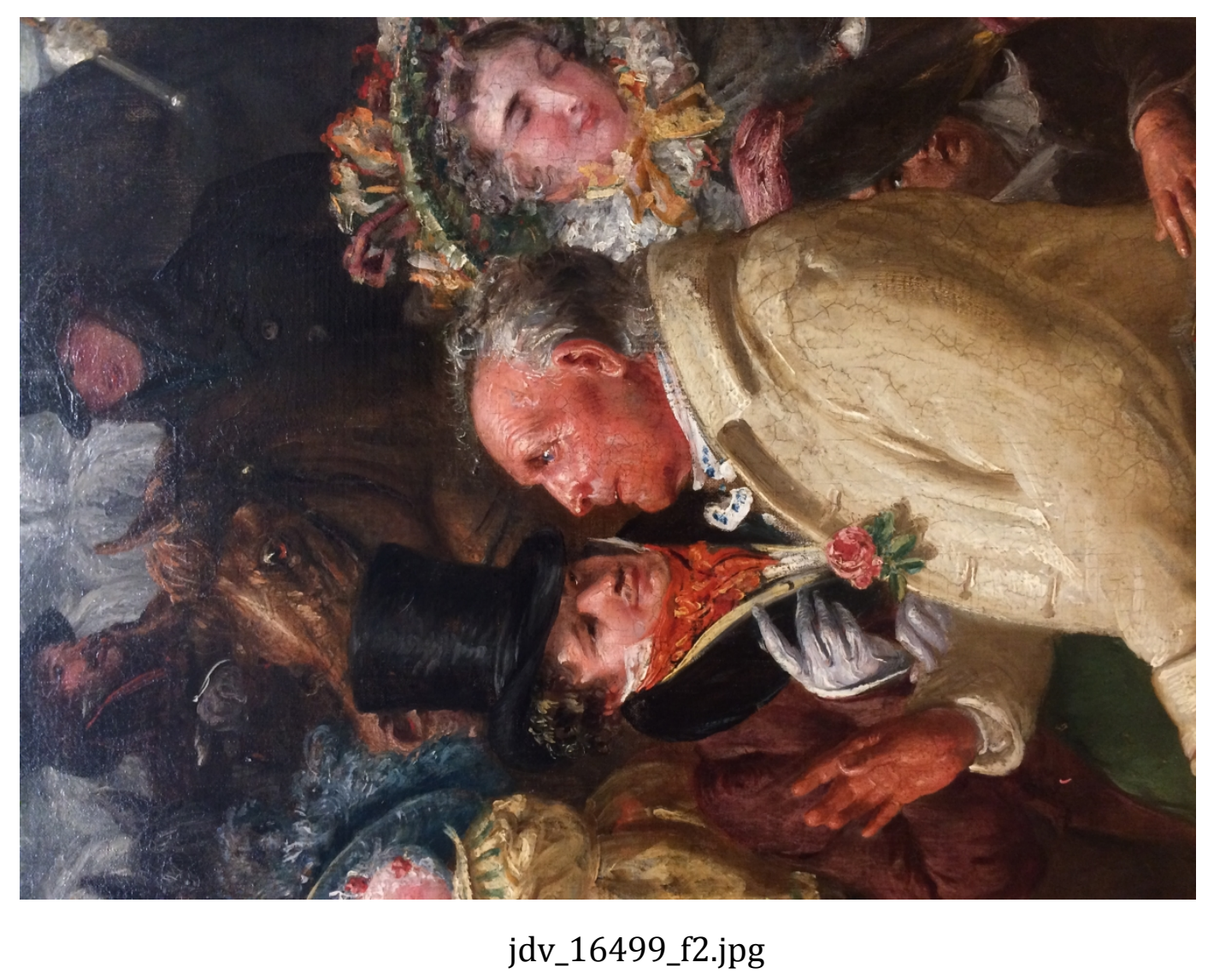

This article is protected by copyright. All rights reserved 